\title{
The Source of the Enterprise Competitiveness: Theoretical Review with Four Viewpoints
}

\author{
Changcai Xie \\ School of Management, Guizhou University, Guiyang, China \\ Email: ccxie@zju.edu.cn
}

How to cite this paper: Xie, C. C. (2021). The Source of the Enterprise Competitiveness: Theoretical Review with Four Viewpoints. Open Journal of Business and Management, 9, 2513-2521. https://doi.org/10.4236/ojbm.2021.95137

Received: July 19, 2021

Accepted: September 23, 2021

Published: September 26, 202

Copyright (c) 2021 by author(s) and Scientific Research Publishing Inc. This work is licensed under the Creative Commons Attribution International License (CC BY 4.0).

http://creativecommons.org/licenses/by/4.0/ (c) (i) Open Access

\begin{abstract}
In the era of economic globalization and knowledge economy, how can enterprises gradually catch up with and even surpass powerful competitors? How can leading enterprises maintain their market position and create sustainable competitive advantage? These two issues have always been a hot topic in the field of strategic management. The success or failure of enterprise management is determined by many factors, and competitiveness is the most important and essential factor. In the new environment, grasping the formation and evolution law of enterprise competitiveness and promoting the sustainable and healthy growth of enterprises is an important topic to be solved in the research of strategic management. On the source of enterprise competitiveness, the academic circles mainly focus on four factors: Resource-based view (RBV), Knowledge-based view (KBV), Capability-based view (CBV) and Institution-based view (IBV).
\end{abstract}

\section{Keywords}

Enterprise Competitiveness, RBV, KBV, CBV, IBV

\section{Introduction}

What is the source of enterprise competitiveness? The simplest answer is the resource and the ability of acquiring and using of resources in a certain regulation. So, what's resource? "Resource" is a very broad concept. Wernerfelt (1984) had defined resource as enterprise who owned tangible and intangible assets semipermanently. In the framework of Barney (1991), resource referred to enterprise controlled all of the assets, capabilities, organization process, enterprise attributes, information and knowledge, which can used to build and implement the strategy to improve efficiency and effectiveness. Barney considered that one resource became the source for enterprise obtaining and maintaining competitive advantage 
when the enterprise possessed the four characteristics with the value, scarce resources, difficult to imitate and hard to replace at the same time. Based on these views, Amit and Schoemaker (1990) thought that resources were the factors of the stock which were owned or controlled by an enterprise. In this paper, we will focus on reviewing the western scholars about the enterprise competitive advantage and the view of competitiveness source.

\section{Theoretical Review with Four Viewpoints}

\subsection{Resource-Based View (RBV) for Enterprise Competitiveness}

Wernerfelt published "A Resource-based View of the Firm" in 1984. After ten years, in 1994, on the anniversary of "Strategic Management Journal", this article was named the most excellent paper. Then, RBV had been generally recognized in the field of business management. The first one who counted enterprise as a resource set was Penrose (1959). This idea was putted in her enterprise growth theory. Penrose maintained that enterprise was a collection of productive resources. The economic function of the collection was set to obtain human resources and other resources in the organization when it provided products or services to the market for profit. Later scholars, in succession Penrose's view, explored the source of enterprise competitive advantage and its mechanism based on the perspective of "enterprise's black box" in the internal structure. After the research by several leading scholars in 80's (Wernerfelt, 1984; Rumelt, 1984; Barney, 1986) and 90's (Barney, 1991; Conner, 1991; Amit \& Sehoemaker, 1993; Wernerfelt, 1995) in twentieth Century, RBV theory which occupied a dominant position in the strategic management field was established and gradually mature.

The core theme study on the RBV was "why the enterprises had differences and how to obtain and maintain competitive advantage" (Rumelt, 1984). The frontal question was answered by Barney (1986) who thought the otherness was reflected in the different resources. The heterogeneity of the enterprises internal resources caused their different profitability. The cultivation, state of internal resources, resource deployment and mode were related to the profit of enterprise (Wernerfelt, 1984; Rumelt, 1984). Wernerfelt (1984) pointed out appraising the enterprise based on resources was a new angle which was different from the traditional ways. Wernerfelt analyzed the relationship between resources and profitability which existed in the form of resource potential barrier, and pointed out that the "first mover advantage" was an attractive resource which could generate high returns on its leading market. Based on the assumption of heterogeneous resources, Rumelt (1984) explained enterprise resources, at the early stage of the life cycle, perhaps were homogeneous. However, with the "isolation mechanism" playing a role, each enterprise would become different increasingly. Their resources, consequently, couldn't be completely imitated and its competitive advantage would be gradually reflected. 


\subsection{Knowledge-Based View (KBV) for Enterprise Competitiveness}

The view of knowledge theory origin can be traced back to the enterprises endogenous growth theory of Marshall (1925). According to Marshall's view, specialization in production process can lead to workers in different levels have different expertise and knowledge, and professional knowledge and skills can lead to further professional production. Penrose (1959) inherited and developed the theory of Marshall, and believed that we should pay more attention knowledge accumulation tendency, especially the "unused knowledge" released during enterprise growths, which decided the direction of enterprise's growth to a great extent.

The direct and major basic of knowledge-based view (KBV) was the theory of RBV. KBV regarded enterprise as the body of knowledge with heterogeneity, and its competitive advantage came from the creation, storage and application of knowledge (Zander \& Kogut, 1995; Conner \& Prahalad, 1996; Spender, 1996). Although knowledge was a sort of very special resource, it also was classified as a kind of enterprise resource. Foss (1996) thought that KBV may help shed light on issues relating to the boundaries and internal organization of the firm. Knowledge is produced and reproduced in a social setting, is inseparable from this setting, and is not fully reducible to individuals. Because of the character of this kind of knowledge and the way it is accumulated through experiences of particularity, particularly in social settings, it is largely path-dependent (Penrose, 1959; Nelson \& Winter, 1982). Nelson \& Winter (1982) created an evolutionary theory of economic changing and stressed the importance of knowledge when it was used to explain organizational variance as a productive resource. They believe that enterprise not only creates knowledge but also has the function of knowledge storage, just like a storage reservoir. Nonaka \& Takeuchi (1995) pointed out that enterprise, due to the existence of uncertainty in the knowledge system, must establish a mechanism to make two types of knowledge conversion in order to make knowledge become the source of competitiveness.

Enterprise's competitiveness of KBV pays attention to the inner and extension strength of enterprise knowledge, such as knowledge creation, knowledge absorption and knowledge integration. Knowledge creation is mainly learning complementary knowledge from partners, designing knowledge transfer mechanism reasonable, and achieving the objective of knowledge creation (Zander \& Kogut, 1995; Grant, 1996). The capability of knowledge absorption, which was positively correlated with learning, was considered to be the main source of knowledge stickiness (Szulanski, 2000). Knowledge integration followed with how to develop skills, how to use knowledge and what was the main way to acquire competitive advantages (Simonin, 1999). Grant (1996) also thought that knowledge integration was the main way to acquire competitive advantages.

\subsection{Capability-Based View (CBV) for Enterprise Competitiveness}

Since Wernerfelt (1984) put forward RBV, many scholars had conducted a lot of 
research and come into the relevant theory in addition to the above representative scholars (Barney, 1986; Barney, 1991; Amit \& Schoemaker, 1993; Foss, 1996; Simonin, 1999; Szulanski, 2000; Zahra \& George, 2002). Although RBV always seen enterprise unique resources and capabilities as the source of competitive advantage, the scholars, who inclined to the capabilities, highlighted the central role of the ability to gain competitive advantage based on the resource theory framework (Prahalad \& Hamel, 1990). CBV demonstrated enterprise competitive advantage from the enterprise unique ability which can help the enterprise to obtain and maintain competitive advantage. These capabilities main are the core competence, absorptive capability and dynamic capability.

\subsubsection{Core Competence}

First people who proposed the concept of core competence were the America famous scholar, Prahalad \& Hamel (1990). Prahalad \& Hamel believed that enterprise was "the set of capability" in essence. The set was manifested by its unique knowledge accumulation which can form heterogeneous resources to obtain a competitive advantage. This heterogeneity was reflected by scarcity, ductility, value and difficult to imitate. The concept of core competence expands the theory of RBV. Prahalad \& Hamel (1990) thought that, in order to develop core products and create a series of final products, the source of sustained competitive advantage lay in each link of the value chain in the collective learning of internal organization. The core competence theory once obtained fast development, but its limitations were also quickly highlighted. In the dynamic and complex environment, the traditional core technology and resource, due to its "relatively viscous", often became a stumbling block in the development of enterprise (Teece et al., 1997).

\subsubsection{Absorptive Capability}

"Absorptive capability" which referred to "the ability of enterprises to identify, digest and utilize of external knowledge" was first proposed by Cohen \& Levinthal (1990). They also pointed out enterprises that grasped the past related knowledge, had an important influence on the absorptive capability level. After that, there were a large number of scholars devoted to research on absorptive capability and expanded the concept. Grant (1996) defined absorptive capability as "the capability of evaluation, acquisition, integration and commercial use of external new knowledge". Absorptive capability included the ability of learning and solving problem. The ability of learning is to digest the knowledge to achieve imitating others and the ability of solving problem is to create new knowledge in order to achieve innovation. Zahra \& George (2002) thought that absorptive capability was a strong guarantee to the competitiveness of enterprises, including the ability of knowledge acquisition, knowledge transformation, knowledge digestion ability and knowledge utilization ability. In fact, Zahra \& George (2002) proposed that the absorptive capability was a dynamic capability which embedded in the convention and processes of organization. This capability developed 
along the changeable directions rather than fixed knowledge acquisition and utilization path.

\subsubsection{Dynamic Capability}

The literature characterizes dynamic capabilities as complicated routines that emerge from path-dependent process (Nelson \& Winter, 1982; Teece et al., 1997; Zollo \& Winter, 1999). However, while path dependence appropriately emphasize the encoding of inferences from the unique histories of firms into distinctive routines, path dependence is more accurately described in terms of learning mechanisms that have been identified principally within the psychological literature (Argote, 1999). These learning mechanisms guide the evolution of dynamic capabilities (Kathleen \& Jeffrey, 2000).

In these views, the representative one was the Dynamic Capability Perspective (Teece et al., 1997). According to this theory, the theory of core competence had some limitations, because in a dynamic environment, the original core competence of enterprise were likely to become a burden which hindered the development of the enterprise, and therefore it cannot explain how enterprises obtained competitive advantage and why some enterprises kept sustainable competitive advantage on the dynamic the market. They defined dynamic capability as the company capacity of integration, construction, re-configuration of internal and external capabilities to respond to the rapidly changing environment.

Kathleen \& Jeffrey (2000) maintained that dynamic capabilities were the clear convention and processes which can be confirmed in the organization. Dynamic capabilities include dynamic resource integration capability (such as product development convention and strategic decision formation), dynamic re-allocation resources capability (such as replication, resale routine, managers use to change and re-combination of resources), dynamic obtaining and transferring resource capability (such as the routines of knowledge innovation and knowledge acquisition from the outside). Capabilities were generated and developed in the process of the interaction of long-term specific information based on enterprise tangible or intangible resources (Amit \& Shcoemkaer, 1993). These capabilities characterized the heterogeneity between different enterprises and had the characteristics of hard to be imitated and replaced (Barney, 1986; Mahoney \& Pandina, 1992; Amit \& Sehoemaker, 1993; Peteraf, 1993). Therefore, the dynamic capabilities possess the potential ability of strategic management to grasp opportunities or to avoid threats. It made enterprises acquire location advantage in the approach monopoly market and generate competitive advantage (Rumelt, 1984; Prahalad \& Hamel, 1990).

\subsection{Institution-Based View (IBV) for Enterprise Competitiveness}

From the institutional perspective, enterprise carried their operations under the taken-for-granted assumptions which referred to norms, values, and what constitutes appropriate and acceptable economic behavior (Oliver, 1996). Institu- 
tion-based View (IBV) was developed for each level of analysis, based on the interaction of resource-based and institutional factors, to explain when managers will be more likely to make optimal resource choices, and when optimal resource choices will be more likely to lead to firm heterogeneity and economic rents.

The institutional view suggested that the motives of human behavior extended beyond economic optimization to social justification and social obligation ( $\mathrm{Zu}$ kin \& DiMaggio, 1990). Institutional theorists were especially interested in how organizational structures and processes became institutionalized over time (Meyer \& Rowan, 1977; Scott, 1987; Zucker, 1987). Institutionalized activities were those actions that tend to be enduring, socially accepted, resistant to change, and not directly reliant on rewards or monitoring for their persistence (Oliver, 1992). According to the institutional theorists' perspective, organizational behaviors should be adaptation and be restrained by social environment. Therefore, enterprises that obtained sustainable competitive advantage urged their economic behaviors to meet the institutional specification.

\section{Conclusion}

In a word, combining $\mathrm{RBV}, \mathrm{KBV}, \mathrm{CBV}$ and IBV can solve or release the contradiction between the economic rationality and regulation rationality on the resource selection decision (Wei, 1999). Whether the selection and allocation of resources support the realization of the goal of economic rationality and the acquisition of sustainable competitive advantage must be verified through the innovation process. For example, if the research focus of the resource view is the energy necessary for the enterprise to drive the train to the target, the system view is to design the track for the train to run, while the innovation view is to solve the whole process of how to make the train reach the destination, and the end point of the train is the economic rationality based on obtaining competitive advantage.

If the economic rationality (ER) was the companies' objective function, resources, knowledge and capability were the necessary tools which promoted the objective function to achieve economic rationality, and the regulation rationality (RR) was the key constraint function. As follows:

$$
\begin{aligned}
\mathrm{ER} & =f(\mathrm{RBV}, \mathrm{KBV}, \mathrm{CBV}) \\
\text { s.t.RR } & =f(\mathrm{IBV})
\end{aligned}
$$

Wei (1999) thought that the enterprise's sustainable competitive advantage came from the sustained innovation ability on the basis of institutional specification and resource heterogeneity. The heterogeneous capability pool of enterprises is the source of sustainable competitive advantage, and dynamic capability is the ability to form and reconstruct the organizational capability pool and use its capability pool to shape effective enterprise behavior. Dynamic capability refers to the key processes of the enterprise, especially the processes of integration, reorganization, acquisition and transfer of resources, so as to match and even 
create market changes. However, with the rapid development of information technology and the globalization process, enterprises should pay a great attention to the resources flowing between different enterprises. Under these circumstances, the base of "resources with sticky" will be doubt. This study is limited to the theoretical level and the rationality still needs inspection and improvement in the next step to practice and research. Of course, due to the differences in research perspectives and backgrounds, relevant theories, viewpoints or schools are always the first to show as a complex "Jungle", and the source of enterprise competitiveness is no exception. It is the only way out of the "Jungle" to study and sort out these theories, viewpoints or schools in time and find out the connections and laws between them. This paper has done some preliminary work, hoping to get the effect of throwing bricks and attracting jade.

\section{Conflicts of Interest}

The author declares no conflicts of interest regarding the publication of this paper.

\section{References}

Amit, R., \& Schoemaker, P. J. (1990). Key Success Factors: Their Foundation and Application. Working Paper, Northwestern University.

Amit, R., \& Schoemaker, P. J. (1993). Strategic Assets and Organizational Rent. Strategic Management Journal, 14, 33-46. https://doi.org/10.1002/smj.4250140105

Argote, L. (1999). Organizational Learning: Creating, Retaining, and Transferring Knowledge. Kluwer Academic.

Barney, J. B. (1986). Organizational Culture: Can It Be a Source of Sustained Competitive Advantage? Academy of Management Review, 11, 656-665. https://doi.org/10.5465/amr.1986.4306261

Barney, J. B. (1991). Firm Resources and Sustained Competitive Advantage. Journal of Management, 17, 99-120. https://doi.org/10.1177/014920639101700108

Cohen, W. M., \& Levinthal, D. A. (1990). Absorptive Capacity: A New Perspective on Learning and Innovation. Administrative Science Quarterly, 35, 128-152. https://doi.org/10.2307/2393553

Conner, K. R. (1991). A Historical Comparison of Resource-Based Theory and Five Schools of Thought within Industrial Organization Economics: Do We Have a New Theory of the Firm? Journal of Management, 17, 121-154.

https://doi.org/10.1177/014920639101700109

Conner, K. R., \& Prahalad, C. K. (1996). A Resource-Based Theory of the Firm: Knowledge versus Opportunism. Organization Science, 7, 477-501.

https://doi.org/10.1287/orsc.7.5.477

Foss, N. J. (1996). Knowledge-Based Approaches to the Theory of the Firm: Some Critical Comments. Organization Science, 7, 470-476. https://doi.org/10.1287/orsc.7.5.470

Grant, R. M. (1996). Toward a Knowledge-Based Theory of the Firm. Strategic Management Journal, 17, 109-122. https://doi.org/10.1002/smj.4250171110

Kathleen, M. E., \& Jeffrey, A. M. (2000). Dynamic Capabilities: What Are They? Strategic Management Journal, 21, 1105-1121. 
https://doi.org/10.1002/1097-0266(200010/11)21:10/11<1105::AID-SMJ133>3.0.CO;2$\underline{E}$

Mahoney, J. T., \& Pandian, J. R. (1992). The Resource-Based View within the Conversation of Strategic Management. Strategic Management Journal, 13, 363-380. https://doi.org/10.1002/smj.4250130505

Marshall, A. (1925). Principles of Economics. MacMillan.

Meyer, J. W., \& Rowan, B. (1977). Institutional Organizations: Formal Structure as Myth and Ceremony. American Journal of Sociology, 80, 340-363. https://doi.org/10.1086/226550

Nelson, R. R., \& Winter, S. G. (1982). An Evolutionary Theory of Economic Change. Belknap Press.

Nonaka, I., \& Takeuchi, H. (1995). The Knowledge-Creating Company: How Japanese Companies Create the Dynamics of Innovation. Oxford University Press.

Oliver, C. (1992). The Antecedents of Deinstitutionalization. Organization Studies, 13, 563-588. https://doi.org/10.1177/017084069201300403

Oliver, C. (1996). The Institutional Embeddedness of Economic Activity. In J. A. C. Baum, \& J. Dutton (Eds.), Advances in Strategic Management (Vol. 13, pp. 163-186). JAI Press.

Penrose, E. T. (1959). The Theory of the Growth of the Firm. Oxford University Press.

Peteraf, M. A. (1993). The Cornerstones of Competitive Advantage: A Resource-Based View. Strategic Management Journal, 14, 179-191. https://doi.org/10.1002/smj.4250140303

Prahalad, C. K., \& Hamel, G. (1990). The Core Competence of the Corporation. Harvard Business Review, 66, 79-91.

Rumelt, R. P. (1984). Towards a Strategic Theory of the Firm. In R. Lamb (Ed.), Competitive Strategic Management (pp. 556-570). Prentice-Hall.

Scott, W. R. (1987). The Adolescence of Institutional Theory. Administrative Science Quarterly, 32, 493-511. https://doi.org/10.2307/2392880

Simonin, B. L. (1999). Ambiguity and the Process of Knowledge: Transfer in Strategic Alliances. Strategic Management Journal, 9, 595-623.

https://doi.org/10.1002/(SICI)1097-0266(199907)20:7<595::AID-SMJ47>3.0.CO;2-5

Spender, J. C. (1996). Making Knowledge the Basis of a Dynamic Theory of the Firm. Strategic Management Journal, 17, 45-62. https://doi.org/10.1002/smj.4250171106

Szulanski, G. (2000). The Process of Knowledge Transfer: A Diachronic Analysis of Stickiness. Organizational Behavior and Human Decision Process, 82, 9-27. https://doi.org/10.1006/obhd.2000.2884

Teece, D. J., Pisano, G., \& Shuen, A. (1997). Dynamic Capabilities and Strategic Management. Strategic Management Journal, 18, 509-533. https://doi.org/10.1002/(SICI)1097-0266(199708)18:7<509::AID-SMJ882>3.0.CO;2-Z

Wei, J. (1999). Sustainable Competitive Advantage: System View, Resource View and Innovation View. Journal of Dialectics of Nature, No. 2, 39-45.

Wernerfelt, B. (1984). A Resource-Based View of the Firm. Strategic Management Journal, 5, 171-180. https://doi.org/10.1002/smj.4250050207

Wernerfelt, B. (1995). The Resource-Based View of the Firm: Ten Years after. Strategic Management Journal, 16, 171-174. https://doi.org/10.1002/smj.4250160303

Zahra, S., \& George, G. (2002). Absorptive Capability: A Review, Reconceptualization, 
and Extension. Academy of Management Review, 27, 185-203.

https://doi.org/10.5465/amr.2002.6587995

Zander, U., \& Kogut, B. (1995). Knowledge and the Speed of the Transfer and Imitation of Organizational Capabilities: An Empirical Test. Organization Science, 6, 76-92. https://doi.org/10.1287/orsc.6.1.76

Zollo, M., \& Winter, S. G. (1999). From Organizational Routines to Dynamic Capabilities. Working Paper WP 99-07, University of Pennsylvania.

Zucker, L. G. (1987). Institutional Theories of Organizations. Annual Review of Sociology, 13, 443-464. https://doi.org/10.1146/annurev.so.13.080187.002303

Zukin, S., \& DiMaggio, P. J. (1990). Introduction. In S. Zukin, \& P. J. DiMaggio (Eds.), Structures of Capital: The Social Organization of the Economy (pp. 1-56). Cambridge University Press. 